dead, including the team's leader Enrico Fermi, Arthur H. Compton and Leo Szilard. Among those to be honoured by the university this week will be Robert Duffield, director of the Argonne National Laboratory.

The enthusiasts for commercial exploitation of the nuclear reaction have, in the United States at least, further cause for celebration. This year marks the tenth anniversary of the first sale of electricity generated by a nuclear power station. (The Schippingport reactor in Pennsylvania, with a new core, is still serving Pittsburgh today.) The boom in orders for new power plants is continuing; twenty-six were made known in the first three-quarters of this year compared with twenty-three in the corresponding period last year. And the contract has just been signed for southern California's combined nuclear power and desalination plant, expected to be not only the world's biggest, but one of the cheapest in terms of the delivered cost of its desalted water.

Moreover, next week should see the first nuclear explosion sponsored jointly by the Atomic Energy Commission and private industry to test the peaceful (that is, commercial) possibilities of such explosives. Project Gasbuggy, as someone has thought fit to label it, will consist of a 26 kiloton explosion $4,000 \mathrm{ft}$. down in the sandstone formations near Farmington, New Mexico. The AEC and the El Paso Natural Gas Company want to see whether the blast can release the gas locked up in an otherwise unprofitable gas field. The AEC has at least six other commercial experiments scheduled-one to get at oil, another at copper. Conceivably some day the commission could be in such heavy demand as a blaster that it might have to contract out the business of setting off nuclear explosions to a private company.

\section{Discovery of X-rays}

ON November 8, 1895, W. C. Röntgen, professor of physics at Wurtzburg University, observed a phenomenon which led to his discovery of X-rays. Almost immediately after the discovery, applications blossomed at a remarkable rate, and some fell even within the ambit of the original discovery itself. Even today, when the importance of the rapid application of new ideas is widely appreciated, this rate of application is rarely if ever equalled. Dr D. Chilton of the Science Museum discussed the reasons for the rapid application of Röntgen's discovery in a paper to the history of science discussion group at the Royal Institution on November 15.

One reason for Röntgen's success seems to have been the remarkable speed at which he worked. Dr Chilton quoted from a speech by Professor Ewald-“"Röntgen was a character who hated to part with an unfinished experiment by publishing it. He made the chance observation on November 8 and, working feverishly in the next six weeks, found nearly all the properties of $\mathrm{X}$-rays which were to be known within the next ten years ... Physicists and medicals alike tried to find out more about the properties of these rays than Röntgen had indicated in his ten-page pamphlet which he sent out to his friends as a New Year's gift." The reaction was certainly remarkable; Dr Chilton said that by the end of April 1896, there had been sixty-one references to $\mathrm{X}$-rays in the pages of Nature, an average of three to four each week. By February 1, the Lancet was reporting that the invention was so far advanced that in Belgium it was being brought into practical use in the hospitals. This was just one month and three days after the first announcement of the discovery.

Other applications were also quickly realized, Dr Chilton said. Röntgen himself noted the way in which $\mathrm{X}$-rays showed up lack of homogeneity in a metal structure, now the basis for industrial testing of metals. S. P. Thompson showed that gem stones and their glass imitations differ in their absorption of X-rays. All this, Dr Chilton said, was derived almost directly from Röntgen's first paper.

Röntgen's "chance observation" came when he was working on electric discharges within an evacuated glass tube. Working in a darkened room with the tube enclosed in black paper, he noticed that a film of barium platinocyanide, a well-known fluorescent material, showed a bright fluorescence whenever the tube was operating nearby. But if the discovery was a piece of luck, from then on Röntgen left nothing to chance.

\section{New Building at Teddington}

Mr Robert Mellish, Ministel of Public Building and Works, cut the traditional sod on November 28 to mark the site of a new laboratory building at the Ministry of Technology's National Physical Laboratory at Teddington.

The laboratory, which will be known as Petavel Building after Sir Joseph Petavel, a former director of the NPL, should cost about $£ 650,000$. The NPL is already the third largest research establishment in Britain and the new three storey building will provide an extra $34,000 \mathrm{sq}$. ft. of laboratory space and $21,000 \mathrm{sq}$. ft. for offices. The main building will consist of a central reinforced concrete core containing the main staircase, lift and common services. Surrounding this will be the laboratories which, on each floor, will be divided into seven zones, each sub-divided into areas by low partitions. Although the laboratories will be without windows, thereby permitting an economical design for the engineering services, the artificial lighting and air conditioning will, however, provide a stable environment for research. The offices will be located on the perimeter of the building and will have natural light and ventilation.

Petavel Building, which should be completed by September 1969 , is a departure from the normal type of research building. It has been essentially designed to meet the changing needs in research; as $\mathrm{Mr}$ Mellish put it, "Petavel Building is, we believe, a good answer to the request for a general purpose laboratory which would provide the conditions required for a wide range of the National Physical Laboratory's work and which would also be capable of modification to provide other conditions with a minimum of expense". The contractors began work on November 29, and it looks as if the ministry is determined to have the building finished on time.

\section{Protein from Petroleum}

INTERESTING results have been obtained from experiments in which yeast cells have been used to produce 